\title{
Causes of Project Delay: A Case Study on Clifton (Sewage) Pumping Station
}

\author{
Muhammad Najeeb Adam Sayed Fayaz Ahmad \\ Institute of Business Management, Karachi
}

\begin{abstract}
This case study finds out the factors of delays in Clifton Pumping Station Project i.e. a scheme that was proposed by Government of Sindh for rehabilitation / Construction of Civil, Mechanical Infra-structure along with replacement of by-pass arrangements for proper functioning of Clifton Pumping Station for ultimate disposal at Mai-Kolachi STP to be constructed by KPT under SIII (KW \& SB) Project. The main reasons for delays were analyzed, comprised of: Inadequate Funding, Original Assumptions Invalid, Non-availability of Old As-built Drawings, Changes in Business Priorities, and Difficulties in Execution Works in Red-Zone Area, Nonavailability of Ready-Mix, and Major Delays in taking approvals. The findings and lesson learned from this case study shall be beneficial for future execution works that will provide a basis for strategies to minimize delays, not only for the Contractors but also for Consultants and Employers respectively.
\end{abstract}

Keywords: Project Delay, Construction Projects and Delay Causes

DOI: $10.7176 /$ CER/11-5-01

Publication date:June $30^{\text {th }} 2019$

\section{INTRODUCTION}

It is widely accepted that a project is successful when it is finished on time but unfortunately, due to many reasons, a large number of construction projects fail to meet their original contact time [1]. The problem of delays in the construction industry is a global phenomenon. Construction projects often suffer from poor performance in terms of time delays, cost overruns and quality defects. One of the earlier studies on delay's factors in Projects has identified 10 most important causes of delay i.e. (1) contractor's improper planning, (2) contractor's poor site management, (3) inadequate contractor experience, (4) inadequate client's finance and payments for completed work, (5) problems with subcontractors, (6) shortage in material, (7) labor supply, (8) equipment availability and failure, (9) lack of communication between parties, and (10) mistakes during the construction stage. Six main effects of delay were: (1) time overrun, (2) cost overrun, (3) disputes, (4) arbitration, (5) litigation, and (6) total abandonment [2]. The variation in the project scope is one of the major reasons in its delayed completion and causing the negative impact on the development of country economic growth and prosperity. The five most significant delay causes as seen were cash flow and financial difficulties faced by contractors, contractor's poor site management, inadequate contractor experience, shortage of site workers and ineffective planning and scheduling by contractors and its three most significant effects were time overrun, cost overrun and arbitration [3]. This case study on Clifton Pumping Station identifies the factors that caused delay and also contains the informative points and knowledge areas for the Project Stake-holders in order to overcome the delays in works and project completion.

\section{LITERATURE REVIEW}

Planning was the most harmful delay cause on time performance [4]. Project Planning involves identifying and listing a specific number of project goals, features, functions, deliverables and tasks. Cost and time overruns are the key problems of any construction projects. Construction delays are often due to miscommunication between contractors, subcontractors, owners and suppliers. These types of unrealistic exceptions are usually avoided by using a clean and efficient planning mechanism, which clearly specifies the work and timetable to be used. Delays in construction projects are quite expensive; sometimes they may result in severe damages to the involved parties [5]. The deterioration of the relationship between project parties may increase the likelihood of poor performance. These issues are causing the negative impact on the development of country economic growth and prosperity [6]. There are two main type of delay: excusable delay and non-excusable delay [7]. There factors that induce delay on construction projects includes: lack of funds to finance the project to completion, changes in drawings, lack of effective communication among the parties involved, lack of adequate information from consultants, slow decision making and contractor's insolvency, variations among others [8]. The owner interference, inadequate contractor experience, financing and payments, labor productivity, improper planning, and subcontractors are also most important factors [9]. From the analysis, most critical factors of construction delay were identified as (1) lack of commitment; (2) inefficient site management; (3) poor site coordination; (4) improper planning; (5) lack of clarity in project scope; (6) lack of communication; and (7) substandard contract [10]. It is concluded in one of the paper that $76 \%$ of the contractors and $56 \%$ of the consultants indicated that average of time overrun is between $10 \%$ and $30 \%$ of the original duration. The most common cause of delay 
identified by all the three parties is "change order". Surveys concluded that $70 \%$ of projects experienced time overrun [11]. In short, The most common factor of delay are natural disaster in Pakistan like flood and earthquake and some others like financial and payment problems, improper planning, poor site management, insufficient experience, shortage of materials and equipment etc. [12]

\section{THE CPS PROJECT}

\subsection{ProJeCT BRIEF}

- Project Title

- Name of Scheme

- Client / Employer

- Consultant

- Contractor

\author{
Clifton (Sewage) Pumping Station - CPS \\ Construction of Clifton (Sewage) Pumping Station
}

Adjacent to CID Centre Severally Damaged / Massive Destruction Occurred Due to Heavy Explosive Attack by the Terrorists at CID Centre Adjacent to Clifton Pumping Station

Karachi Water \& Sewerage Board (KW\&SB)

Techno Consult International (TCI)

KSB - ATL Consortium

(Consortium of M/s: KSB Pumps Co. Ltd. and Al-Tariq Constructors (Pvt.) Ltd.

\subsection{SCOPE OF WORK}

- To rehabilitate the Clifton Pumping Station from explosion damage.

- To provide for the differed maintenance and modernized the facilities.

- To enhance the pumping capacity in consideration of future sewage requirement.

- To construct Single-Storey (Ground plus one) Administration Block for Operation Staff and KW\&SB officers.

\subsection{BACKGROUND}

The Clifton Pumping Station (CPS) was constructed in 1964 to lift the sewage of most of the commercial centre of Karachi and was known as PS-1. Later in the year 1992, the pumping station was upgraded by an additional pumping station having four pumping units and was known as PS-2.

The Clifton Pumping Station (CPS) is constructed on 5,535 $\mathrm{m} 2$ and houses two pumping stations equipped with standby Generator and other allied accessories. Administration Block is also available for the Engineers along with operational and Support Staff. The station used to deal with nearly 24 MG of sewage from Bath Island, Clifton, Civil Lines, Old City Area, I.I. Chundrigar Road, Saddar and adjoining areas on daily basis. After completion, the pumping station will be able to treat 40 MGD.

On November 11, 2010 in an act of terrorism, heavy explosive attack took place at CID Centre Beaumont Road Civil Lines adjacent to Clifton Pumping Station; KW \& SB. Beside massive destruction of CID Centre, the CPS was also damaged badly causing stoppage of all operational activities. The Civil and Mechanical Infra-structure at Pump Houses became non-functional.

Due to sudden suspension of Sewage Pumping immediately sewage over-flowing started at their catchment area which causes unhygienic condition to the General Public \& VVIP's. Therefore on top emergent basis, interim relief given to general public by fixing diesel sewage pumps (trolley mounted) as 01st Phase. Although temporary arrangements were made for the disposal of sewage but it is very essential to rehabilitate / construct all Civil, Mechanical Infra-structure including replacement of by-pass arrangements to facilitate permanent relief to general public to avoid unhygienic condition.

\subsection{Catchment Area of Clifton Pumping Station}

Clifton pumping station is very important and located in highly sensitive area which encompasses high profile government and private offices / residences like Honorable Supreme \& High Courts, Chief Minister House, Governor House, Core Commander House, Foreign Councils, Five Star Hotels, Offices of MNC's etc which caters the sewage of huge population especially Saddar Town, and it's all adjoining areas. The sewage generated from a large area of old city, Saddar, Clifton and adjoining localities was being lifted through CPS. The Sewage Trunk Mains of $1200 \mathrm{~mm}$ dia from Saddar, $1370 \mathrm{~mm}$ dia from I.I. Chundrigar Road, $1370 \mathrm{~mm}$ dia from Cifton converge into a single 72 inch trunk sewer which transmit the sewage to the intake channel of the pumping station.

\section{DELAY CAUSES (REASONS FOR PROJECT DELAY)}

\subsection{Inadequate Funding}

After the letter of acceptance (LOA), provide by an employer on August 2013 and subsequently the letter of commencement provided by the Consultant on October 2013, the contactor has requested for 'Mobilization 
Advance against the Bank Guarantee' from the Employer to cover the initial project expenses. On account of annually applicable bank KIBOR, the Mobilization Advance has been provided which ultimately supports contractor to take-up the upfront challenges during the site mobilization for work execution. This project is funded by Government of Sindh and the funds were unavailable approximately for a year i.e. From August 2014 to August 2015 caused the delay in work schedule. The Project Cash Flow was affected and Contractor's Higher Management has slow-down the activities requiring greater cost / expenses. The same results was also observed by another studies [13] [14].

During this during of non-availability of Project Fund, the Contractor has submitted 03 running Interim Payment Applications which were converted into IPC (after the certification from Consultant) but Payments were on hold and consequently the Consortium Management has decided to adjust the Mobilization Advance at least to keep safe from the applicable future interest amount on it. However, the Contractor has claimed the interest on delayed payment in accordance with the contractual provision of project.

\subsection{Original Assumptions Invalid}

A) Delay in the approval of Variation order for Earthing Works as the Original Design and Work Scope has been Changed

The initial scope of Earthing work in Contract was comprised of: Preparation of 08 Nos. earth Pits as per IS: 3043 by supply and installation of earth electrodes of $600 \mathrm{~mm}$ X $600 \mathrm{~mm}$ X $6 \mathrm{~mm}$ size copper plate and all other accessories like watering pipe, funnel, chamber, cast iron cover etc. along with the Providing and Fixing copper strip 6 X $30 \mathrm{~mm}$. However, due to the space / land limitation, the implementation of this design is not much feasible and requisite Bore-Type Rod Earthing.

The contractor has intimated the real site issues with respect to the original design to the designer / consultant and requested for the provision of Variation Order for proceeding works pertaining to the new design and quantity which were extended to 14 Nos. of Earth Pits and includes different size of Copper Conductor for various equipments and machinery by replacing the copper strip There was the notable delay in project schedule in executing the works (which includes procurement, installation, and testing of earth pits), after the formal approval of variation order of Earthing Works.

\section{B) Unforeseen RCC duct in front of Pumping Station connecting Channel}

As the massive destruction occurred due to heavy explosive attack, the scope of works comprised of the 'Demolition and Removal of existing structures of plain or reinforced concrete or masonry within the permanent works and disposal of demolish material to designated disposal areas within $15 \mathrm{Km}$ along with the Dismantling of equipment and Machinery, complete as per instruction of Engineer in charge / Consultant. So after the Demolition and removal of existing Pumping Station Structure, the contractor has identified the RCC duct in front of the Pumping Station where the Contractor was supposed to excavate in depth at Channel. The efforts made on this duct, consumed a lot of time but unable to get success as required for smooth execution. Therefore this original assumption was invalid and Contractor has asked the Consultant and Employer for the Design Change and requested to allow the Construction of New Channel for Pumping Station but Shifting the Location of New Pump House. This request was honored and accepted after the several meetings and discussions, caused the severe delay in project schedule.

\section{C) Original Project Time-Frame was Unrealistic}

The original plan for the completion of works (in 09 months) was unrealistic since it did not include the realistic time required for procuring some of the major equipment/machinery and customize products from suppliers, which normally takes around 18 - 20 months approximately.

\subsection{Non-availability of Old As-built Drawings}

The delays encountered due to non availability of as built drawings of old civil structures needed for the installation of pen-stocks, interconnection activities. Moreover, the excavation works planned time has been changed and seems to be unrealistic due to the non-availability of old utilities drawing as the excavation works were carried out manually without the excavator.

\subsection{Change in Business Priorities}

In accordance with our contractual requirement, the scope of E\&M Generator Room was comprised of 'Providing and Fixing stand by Diesel Generating set direct injection turbocharged after cooled of rating 1000 KVA / $800 \mathrm{KW}$ with control panel and accessories.' The initial submission, the contractor made was of Cummins (UK Based) which took around 04 months in getting an approval from Consultant. After approval, the employer's opinion about the Cummins DG Set has been changed and employer has asked the contractor to procure Mitsubishi DG Set for which again the approval took 2 months. After, approval, ordering and lead time caused the severe delay in project planned time-line. 


\subsection{Difficulties in Executing Works (in Red Zone Area)}

As the project site located under the Red-Zone Area, therefore the contractor has faced lot difficulties in transportation of material and in delivery of equipment and heavy machinery at project site cased delay in project schedule. This was also pointed by a research study [15].

\subsection{Non-availability of Ready-Mix}

The project site doesn't contain the sufficient space to place the mixer machinery for preparation of Concrete / Cement in accordance with the required ratio. Therefore the construction has been made via taking Ready mix from the supplier. Unfortunately, a month strike of transporter caused the delay in completion of construction works around 02 months.

\subsection{Delays in Approvals}

The contractor has faced the accumulated effect in getting work done at planned schedule due to the delay in approvals of submittal and redesigning from the consultant / designer side.

\subsection{Acceptance and Consideration of Time Extension by Employer}

On the cited reasons, the contractor has requested the consultant and employer for the time extension which was accepted on ground realities against the condition of no additional cost to employer. The project successfully completed in the provided extension of time by the contractor.

\section{DISCUSSION AND CONCLUSION}

The above arguments shows that it is very unfortunate for organizations and personals that they do not understand the severity of projects. Usually, projects are started with lesser knowledge about the project and without prior market or site information [16] which not negatively impact the project success but also minimizes the organizational image and competitive advantage [17] [18]. Before starting a project proper training and orientation is necessary for all the employees in order to fill the gap of knowledge and understand their importance and part in decision making [19] [20]. It is also necessary to look into the societal factors while starting a project are taking project decisions. As the people controls society and having strong relationship with a political government [21], mostly governments do not create transportation issue, parking issue [22] etc to public due to construction project.

The few major reasons in delaying this referred project are mentioned in this study work. The lesson learned shall be beneficial for future execution works not only for the Contractor but also for Consultant and Employer. The study finding concludes, the delays are always measured as expensive to all parties concerned in the projects and very often it will result in clash, claims, total desertion and much difficult for the feasibility and it slows the growth of construction sector. The project was successfully inaugurated in September 2016 by the Government of Sindh and handed over to Employer in 2018 after the satisfactorily completion of O \& M and DLP period, accordingly.

\section{REFERENCE}

[1] G. A. Niazai and K. Gidado, "Causes of Project Delay in the Construction Industry in Afghanistan," 2018.

[2] M. Sambasivan and Y. W. Soon, "Causes and effects of delays in Malaysian construction industry," Int. J. Proj. Manag., 2007.

[3] M. R. Abdullah, a a A. Azis, and I. A. Rahman, "Potential Effects on Large Mara Construction Projects Due To Construction Delay," Int. J. Integr. Eng. 2013, 2013.

[4] A. Rauzana, "Analysis of Causes of Delay and Time Performance in Construction Projects," IOSR J. Mech. Civ. Eng., 2016.

[5] P. J. Keane and A. F. Caletka, Delay Analysis in Construction Contracts. 2009.

[6] R. K. Shah, "An Exploration of Causes for Delay and Cost Overruns In Construction Projects: Case Study of Australia, Malaysia \& Ghana," J. Adv. Coll. Eng. Manag., 2016.

[7] N. Hamzah, M. A. Khoiry, I. Arshad, N. M. Tawil, and A. I. Che Ani, "Cause of construction delay Theoretical framework," in Procedia Engineering, 2011.

[8] J. D. Owalabi et al., "CAUSES AND EFFECT OF DELAY ON PROJECT CONSTRUCTION DELIVERY TIME," Int. J. Educ. Res., 2014.

[9] A. M. Odeh and H. T. Battaineh, "Causes of construction delay: Traditional contracts," Int. J. Proj. Manag., 2001.

[10] H. Doloi, A. Sawhney, K. C. Iyer, and S. Rentala, "Analysing factors affecting delays in Indian construction projects," Int. J. Proj. Manag., 2012.

[11] S. A. Assaf and S. Al-Hejji, "Causes of delay in large construction projects," Int. J. Proj. Manag., 2006. 
[12] M. Haseeb, A. Bibi, and W. Rabbani, "PROBLEMS OF PROJECTS AND EFFECTS OF DELAYS IN THE CONSTRUCTION INDUSTRY OF PAKISTAN,” Aust. J. Bus. Manag. Res., 2011.

[13] Khalid at el. Relationship of Project Scope, Top Management Support, Skilled and Competent ProjectTeam and Project Manager's Leadership Qualities with Information Technology Projects. Industrial Engineering Letters ISSN 2224-6096 (Paper) ISSN 2225-0581 (online) Vol.5, No.11, 2015

[14] Khalid at el. Critical Success Factors for IT Projects in the Telecom Sector. Industrial Engineering Letters. ISSN 2224-6096 (Paper) ISSN 2225-0581 (online) Vol.5, No.11, 2015.

[15] Ibrahim at el. Factors Influencing the Performance of Supply Chain Management in Manufacturing Industry of Pakistan. Industrial Engineering Letters, ISSN 2224-6096 (Paper) ISSN 2225-0581 (online) Vol.5, No.8, 2015. Pp. 34-42.

[16] Ahmad, Knowledge Management: Factors Influencing Successful Innovation, Information and Knowledge Management. ISSN 2224-5758 (Paper) ISSN 2224-896X (Online) Vol.2, No.4, 2012

[17] Ibrahim et al. Knowledge Management as a Strategy \& Competitive Advantage: A Strong Influence to Success, a Survey of Knowledge Management Case Studies of Different Organizations. Information and Knowledge Management ISSN 2224-5758 (Paper) ISSN 2224-896X (Online) Vol.5, No.8, 2015.

[18] Ahmad, Knowledge Management as a Pre-requisite of Innovation in Public Sector Organization, Indian Journal of Natural Sciences, ISSN 0976-0997 Vol. 9, issue 52.

[19] Sayed at el. Increasing Performance through Assessed Training (A Human Recourse Management Strategy), Journal of Resources Development and Management, ISSN 2422-8397 An International Peer-reviewed Journal Vol.7, 2015.

[20] Nadir Khan at el. Impact of On-Job Training on Performance of Telecommunication Industry, Journal of Social and Development Sciences, Vol. 3, No. 2, pp. 47-58, Feb 2012 (ISSN 22211152).

[21] S. Fayaz A. Influence of a Civil Society on Political Strategy? Evidence from Pakistan. Research on Humanities and Social Sciences. ISSN 2224-5766 (Paper) ISSN 2225-0484 (Online) Vol.1, No.3, 2011.

[22] Fayaz, Sayed Ahmad. The Role of Decision Maker in Designing a Political Party Strategy (Evidence from Pakistan). Journal of Law, Policy and Globalization. ISSN 2224-3240 (Paper) ISSN 2224-3259 (Online) Vol.1, 2011. 